\title{
Correction to: Design considerations of an IL13Ra2 antibody-drug conjugate for difuse intrinsic pontine glioma
}

\author{
Xiaolei Lian, Dina Kats, Samuel Rasmussen, Leah R. Martin, Anju Karki, Charles Keller and Noah E. Berlow ${ }^{*}$ (D)
}

\section{Correction to: acta neuropathol commun 9, 88 (2021) https://doi.org/10.1186/s40478-021-01184-9}

In the original publication [1] there was an incorrect funding acknowledgement. In this correction article the correct and incorrect funding acknowledgement are published. The original article has been updated.

\section{Incorrect funding}

This study was funded by a grant from the Matthew Larson Foundation for Pediatric Brain Tumors, as well as donations in honor of Calee, Caleb, Nicole, and Andrew.

\section{Correct funding}

This study was funded by a grant from the Matthew Larson Foundation for Pediatric Brain Tumors, as well as donations in honor of Caleb, Caleb, Nicole, and Andrew.
Reference

1. Lian X, Kats D, Rasmussen S et al (2021) Design considerations of an IL13Ra2 antibody-drug conjugate for diffuse intrinsic pontine glioma. acta neuropathol commun 9:88. https://doi.org/10.1186/ s40478-021-01184-9

\section{Publisher's Note}

Springer Nature remains neutral with regard to jurisdictional claims in published maps and institutional affiliations. to the material. If material is not included in the article's Creative Commons licence and your intended use is not permitted by statutory regulation or exceeds the permitted use, you will need to obtain permission directly from the copyright holder. To view a copy of this licence, visit http://creativecommons.org/licenses/by/4.0/. The Creative Commons Public Domain Dedication waiver (http://creativeco mmons.org/publicdomain/zero/1.0/) applies to the data made available in this article, unless otherwise stated in a credit line to the data. 